Eduvest - Journal of Universal Studies

Volume 1 Number 11, November 2021

p- ISSN 2775-3735 e-ISSN 2775-3727

\title{
DOCKING MOLECULAR SIMULATION OF SECONDARY METABOLIC COMPOUNDS ANNONA MURICATA AS ANTI- CANCER
}

Sofyan Hidayatulloh

Muhammadiyah Malang University, Indonesia

E-mail: ucihaitachi45@gmail.com

\begin{tabular}{|c|c|}
\hline ARTICLE INFO & ABSTRACT \\
\hline $\begin{array}{l}\text { Received: } \\
\text { October, } 26^{\text {th }} \\
2021 \\
\text { Revised: } \\
\text { November, } 16^{\text {th }} \\
2021 \\
\text { Approved: } \\
\text { November, } 18^{\text {th }} \\
2021\end{array}$ & $\begin{array}{l}\text { This study aims to test and determine the affinity and } \\
\text { molecular mechanism of Annona muricata to cOX-2 } \\
\text { target protein, which can be used to test the potential of } \\
\text { Annona muricata as an anticancer drug using the } \\
\text { molecular docking in silico method (computer modeling). } \\
\text { By identifying and optimizing guide molecules in the drug } \\
\text { discovery process, this computational chemical technique } \\
\text { can be utilized to accelerate the selection of compounds } \\
\text { to be isolated and synthesized. The research use } \\
\text { descriptive quantitative as a research design and the } \\
\text { experimental factorial design as an approach. The results } \\
\text { of this study indicate that curcumin and its analogues } \\
\text { have potential to became anticancer, and can be used for } \\
\text { further drug development related to anticancer. }\end{array}$ \\
\hline KEYWORDS & Cancer, Anti-Cancer, Annona Muricata \\
\hline (c) (†) (9) & $\begin{array}{l}\text { This work is licensed under a Creative Comm } \\
\text { Attribution-ShareAlike } 4.0 \text { International }\end{array}$ \\
\hline
\end{tabular}

\section{INTRODUCTION}

Cancer is a disease that does not distinguish between one social status and the other and can attack anyone and arises due to abnormal growth of body tissue cells that become cancer cells in their development which can spread to other parts of the body which leads to death. Cancer arises from the transformation of normal cells into tumor cells in a multistage process that generally progresses from precancerous lesions to malignant tumors (Sirait and Sulistiowati, 2014)

\begin{tabular}{|c|c|}
\hline & $\begin{array}{l}\text { Sofyan Hidayatulloh (2021). Docking Molecular Simulation of } \\
\text { Secondary Metabolic Compounds Annona Muricata as Anti-Cancer. } \\
\text { Journal Eduvest. 1(11): 1196-1202 }\end{array}$ \\
\hline $\begin{array}{l}\text { How to cite: } \\
\text { E-ISSN: }\end{array}$ & $2775-3727$ \\
\hline Published by: & https://greenpublisher.id/ \\
\hline
\end{tabular}




\section{Sofyan Hidayatulloh}

Cancer is a major public health problem worldwide and the second leading cause of death in the United States. In 2017, the American Cancer Society (ACS) estimated the number of cancer cases was 1.68 million with 4,600 new cancer diagnoses per day and 600,920 cancer deaths (Siegel et al., 2017). Nationally, the prevalence of cancer in people of all ages in Indonesia in 2013 was 1.4\%o or an estimated 347,792 people, while for East Java Province it was 61,230 people (Rio and Suci, 2017).

COX-2 is an enzyme that plays a role in the metabolism of arachidonic acid in cell membranes. Arachidonic acid metabolism is considered to play a very important role in the occurrence of carcinogenesis. This metabolic pathway is associated with the formation of prostanoids. Prostanoids belong to the subclass of eicosanoids which are converted into prostaglandins, thromboxane and prostacyclin (Singh et al., 2010). Cyclooxsigenase-2 (COX-2) is a key enzyme in the conversion of arachidonic acid to prostaglandins which was first identified 20 years ago. Several studies have suggested the involvement of prostanoids in the pathogenesis of cancer (Grösch et al., 2006, p. 2). In vitro studies have shown that growth factors, tumor promoters and oncogenes induce prostanoid synthesis (Singh et al., 2010). Other studies, through in vivo studies, have shown that arachidonic acid metabolism via the cyclooxygenase pathway is increased in some tumor events in humans and is thought to be mediated by the induction of the COX2 enzyme (Chen et al., 2018; Kern et al., 2006).

The most successful therapies for localized and non-metastatic cancers are surgery and radiotherapy, but they are not effective if the cancer has spread throughout the body. Cancer treatments (Chemotherapy, hormone, and biologic therapy) can reach any organ in the body infected by cancer cells. through the bloodstream. Until now these drugs are the best treatment of choice for metastatic cancer (Chabner and Roberts, 2005). Chemotherapy treatment for cancer still has a drawback that besides destroying cancer cells, it also affects normal cells with high growth rates, such as hair follicles, bone marrow, and gastrointestinal tract cells, causing side effects typical of chemotherapy. Because of this, it is necessary to find new treatments that selectively kill cancer cells without affecting normal cells.

The Annona muricata tree, similar to other Annona species, including Annona squamosa and Annona reticulata is widely used as traditional medicine for various diseases, especially cancer and parasitic infections. Phytochemical tests state that annonaceous acetogenins are the main constituents of Annona muricata (Moghadamtousi, et al., 2015). In addition to annonaceous acetogenin, phytochemical screening results from aqueous and ethanol extracts of soursop leaves contain secondary metabolites such as alkaloids, saponins, terpenoids, flavonoids, coumarins, lactones, anthraquinones, tannins, cardiac glycosides, phenols and phytosterols (Gavamukulya, et al., 2014). Zetolite and Annonaceous acetogenin are the main ingredients in the soursop tree, which have anti-cancer, anti-inflammatory, neuroprotective, anti-Alzheimer's and anti-oxidant activities (Adri and Hersoelistyorini, 2013). Knowing the affinity and molecular mechanism of Annona muricata to the COX-2 target protein, can be used to test the potential of Annona muricata as an anticancer drug using the molecular docking in silico method (Computer modeling). By identifying and optimizing guide molecules in the drug discovery process, this computational chemical technique can be utilized to accelerate the selection of compounds to be isolated and synthesized. As a result, it will be known the ability of Annona muricata to suppress COX-2 receptor overexpression.

\section{RESEARCH METHOD}

The research used descriptive quantitative as a research design and the 
experimental factorial design as an approach. The databases used to predict pharmacokinetics are PubChem, Protein Data Bank, and SwissADME. The structure of plant chemical compounds can be accessed on PubChem in 2D and 3D but the ones chosen in this study are in 2D form because not all compounds can read 3D structures on PubChem. Subsequent research materials are secondary metabolites obtained from the dr.duke website and target proteins which can be obtained from the Protein Data Bank. SMILES inputted into PubChem is a chemical notation designed by computer experts that can be used to interpret a chemical structure accurately and specifically with the help of a computer (Weininger, 1988). The results are Druglikeness and Boiled Egg data which will be used to conclude secondary metabolite compounds with good bioavailability.

\section{A. Experimental}

\section{RESULT AND DISCUSSION}

The databases used to predict pharmacokinetics are PubChem, Protein Data Bank, and SwissADME. The structure of plant chemical compounds can be accessed on PubChem in 2D and 3D but the ones chosen in this study are in 2D form because not all compounds can read 3D structures on PubChem. Subsequent research materials are secondary metabolites obtained from the dr.duke website and target proteins which can be obtained from the Protein Data Bank. SMILES inputted into PubChem is a chemical notation designed by computer experts that can be used to interpret a chemical structure accurately and specifically with the help of a computer (Weininger, 1988). The results are Druglikeness and Boiled Egg data which will be used to conclude secondary metabolite compounds with good bioavailability.

Of the 81 compounds from the Annona muricata tree, analysis was carried out using the SwissADME webserver using the Boiled Egg method with a range according to the white circle on TPSA (0-140); WLOGP $(-2-6,8)$. According to (Mirza, 2019) the Boiled Egg method is able to read two parameters at once, namely Human Gastrointestinal Absorption (HIA) and Blood Brain Barrier (BBB). The egg plot area can be easily read, where the yolk represents the physicochemical space for drugs capable of absorbing BBB and the white space represents the physicochemical space for HIA absorption.

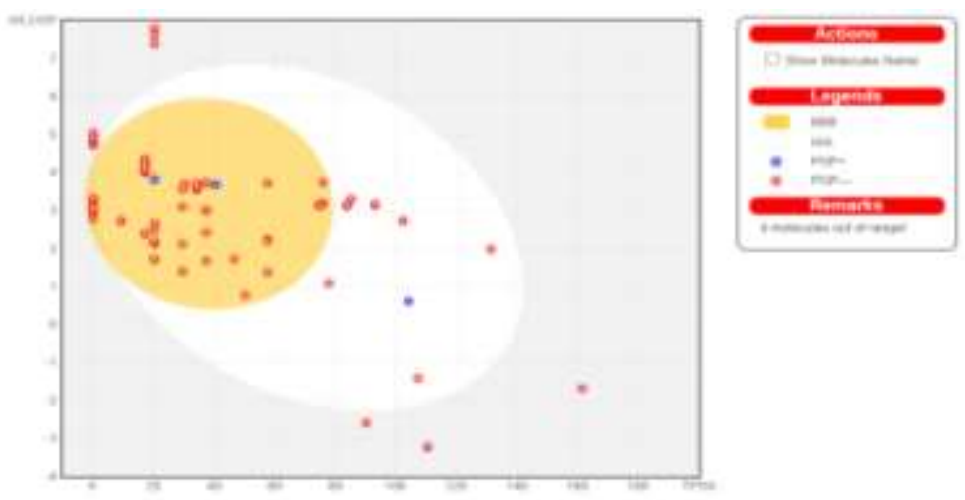

Figure 1. Boiled Egg 


\section{Sofyan Hidayatulloh}

For pharmacodynamic testing, it begins with determining the target protein, in which the criteria is that the target protein to be used must be included in homo sapiens. This is because the target protein to be studied is drug interactions in humans. The selection of the target protein must be complete with ligands because the molecular docking process can only be done with drugs that have ligands. The docking method is said to be valid if the RMSD value is $2 \AA$. In table 3 , the table of the results of the docking method validation shows a lot of RMSD $2 \AA$ this shows that the docking method is valid. The final result of the docking process is the RMSD value, the number of clusters, the Ki value and the binding energy that has been inputted in Table 4. The prediction of ligand interaction activity with the target protein is in the form of binding energy.

The software used for pharmacodynamic profile prediction is Autodock PyRx 0.8 series for docking compounds or drugs, Discovery Studio to separate the contents of the PDB file and also to visualize the final results in $3 \mathrm{D}$ which, for $2 \mathrm{D}$ visualization is done using a webserver. protein.plus. Avogadro is one of the software which has a role in optimizing the geometry for adjusting the atomic structure and bonds. In addition, Avogadro also plays a role in stabilizing molecular geometries so that very small changes in geometry do not change energy (Cahyono, 2019).

The results of the docking simulation carried out 100 times have 100 docking poses that have their respective bond energies. The bond energy taken is the most negative because it has a strong interaction. This is due to the presence of polar functional groups on the ligands such as methyl (-CH3), hydroxyl (-OH) and amine (-NH3).

\section{B. Docking Results Evaluation}

The docking simulation in this study was carried out under flexible ligand conditions. Flexible conditions were used to adjust the structure of the most stable ligand to interact with the receptor. The stability parameter observed was Gibbs free energy $(\Delta \mathrm{G})$. The more negative the value of $\mathrm{G}$ indicates a good level of stability between the ligand and the receptor, so that the bond formed will be stronger. The following table shows the Gibbs free energy $(\Delta G)$ of the docking simulation results.

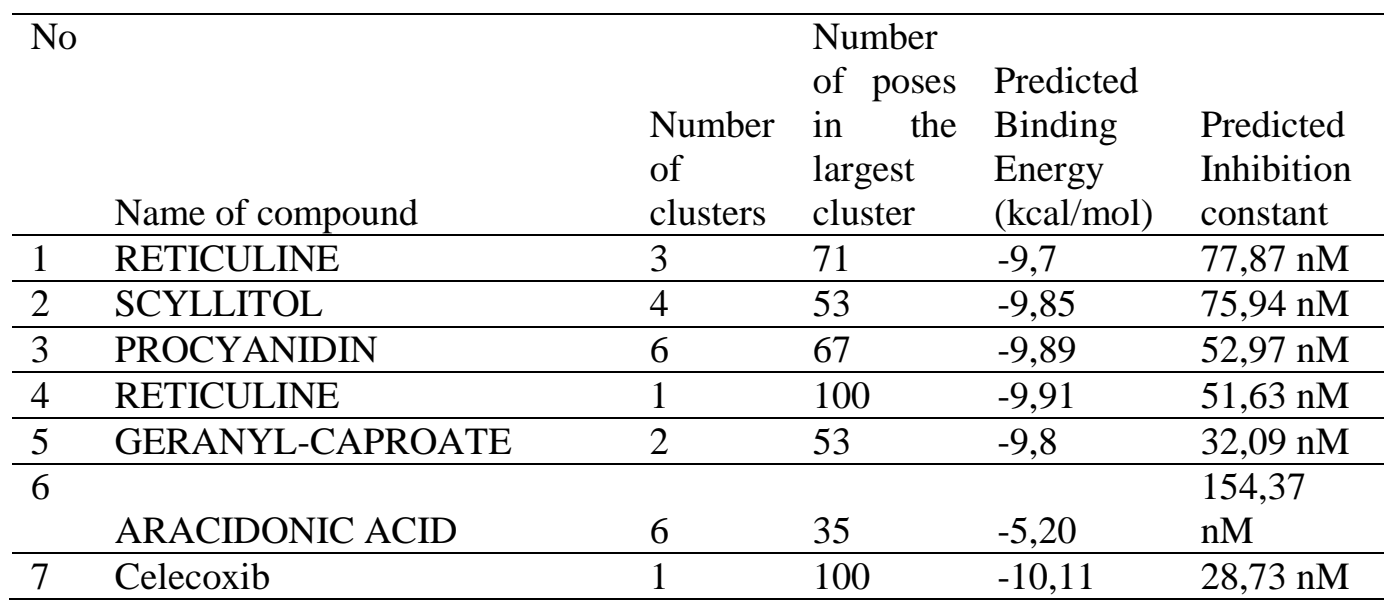

Table 1. The best secondary metabolite compound Annona muricate with the smallest binding energy $(\Delta \mathrm{G})$ and the largest inhibition constant

The results of the docking simulation carried out 100 times have 100 docking poses that have their respective bond energies. The bond energy taken is the most negative because it has a strong interaction. This is due to the presence of polar functional groups in the ligands such as methyl (-CH3), hydroxyl $(-\mathrm{OH})$ and amine (-NH3) in curcumin 
ligands and their analogues.

Secondary metabolite compounds in Annona muricata plant can inhibit arachidonic acid. This is indicated by the value $(\Delta \mathrm{G})$ of Annona muricata compound and its analogues is smaller than that of arachidonic acid $(-5.20 \mathrm{kcal} / \mathrm{mol})$. These data indicate that the Cyclooxyge receptornase-2 (COX-2) will be more stable to bind to compounds in Annona muricata plant and its analogues than arachidonic acid. Arachidonic acid will produce prostaglandins due to enzymatic reactions by the Cyclooxsigenase-2 (COX-2) enzyme so that it can trigger cancer if there is an overexpression of the enzyme. Celecoxib has a lower $G$ value than Annona muricata compound. This indicates that celecoxib can bind more stably to the Cyclooxsigenase-2 (COX-2) enzyme receptor compared to the compound in Annona muricata.

The inhibition constant (Ki) is a value that describes the affinity between the compound and its decomposition. The smaller the Ki value, the greater the affinity of the ligand to the receptor (Arfi et al., 2020). From the table above, it can be seen that the secondary metabolites of Annona muricata have a lower inhibition constant than arachidonic acid. This shows that high affinity is found in the secondary metabolite compound Annona muricata. By having a high affinity, there will be inhibition of the Cyclooxsigenase-2 (COX-2) enzyme, so that prostanoid overproduction can be prevented and will reduce proliferation and apoptosis in cancer cells (Arfi et al., 2020).

\section{Hydrogen Bonds}

Observations of hydrogen bonds and amino acids were carried out using the protein.plus webserver. Chemical bonds other than hydrogen bonds can occur due to flexible ligands interacting with receptors. Interactions can be in the form of non-covalent or non-bonded interactions, which occur between the ligand and the receptor, which can increase the affinity of the ligand to the receptor. The most common bonds are electrostatic interactions and van der Waals bonds.

Table 2. Hydrogen and Hydrophobic Bonds

\begin{tabular}{|c|c|c|c|}
\hline \multirow[t]{2}{*}{ No } & \multirow{2}{*}{$\begin{array}{l}\text { Name of } \\
\text { compound }\end{array}$} & Bond Type & \\
\hline & & Hydrogen & Hydrophobic \\
\hline 1 & RETICULINE & Ser339A, Leu338A & $\begin{array}{l}\text { Val509A, Gly512A, Leu338A, } \\
\text { Ala513A, Ser339A }\end{array}$ \\
\hline 2 & SCYLLITOL & Ser339A & Val509A, Val335A, Ser339A \\
\hline 3 & PROCYANIDIN & $\begin{array}{l}\text { Ile503A, } \\
\text { Tyr341A, } \\
\text { Met508A }\end{array}$ & $\begin{array}{l}\text { Val509A, Ser339A, Phe504A, } \\
\text { Gly512A }\end{array}$ \\
\hline 4 & RETICULINE & - & - \\
\hline 5 & $\begin{array}{l}\text { GERANYL- } \\
\text { CAPROATE }\end{array}$ & $\begin{array}{l}\text { Gln178A, } \begin{array}{l}\text { Phe504A, } \\
\text { Tyr341A, Met508A }\end{array} \\
\end{array}$ & $\begin{array}{l}\text { Phe504A, Gly512A, Val509A, } \\
\text { Ser339A }\end{array}$ \\
\hline 6 & RETICULINE & $\begin{array}{l}\text { Gln178A, Phe504A, } \\
\text { Tyr341A, Met508A }\end{array}$ & $\begin{array}{l}\text { Ser339A, Gly512A, Phe504A, } \\
\text { Val509A }\end{array}$ \\
\hline
\end{tabular}

Table 2 shows hydrogen bonding and amino acid interactions. Table 2 illustrates the hydrogen bonds and amino acids that interact between the Cyclooxsigenase-2 (COX2) enzyme. The docking simulation can also determine the hydrophobic interaction between the ligand and the amino acid residue of the Cyclooxsigenase-2 (COX-2) enzyme in the most stable conformation (small $\mathrm{G}$ value). 


\section{Sofyan Hidayatulloh}

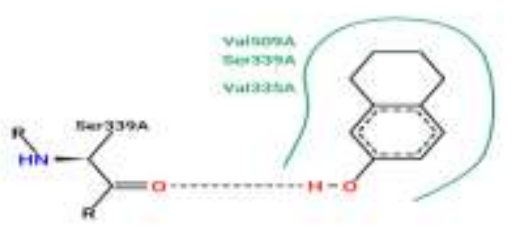

Figure 2. Visualization of Docking EO (Ethinyl Estradiol)

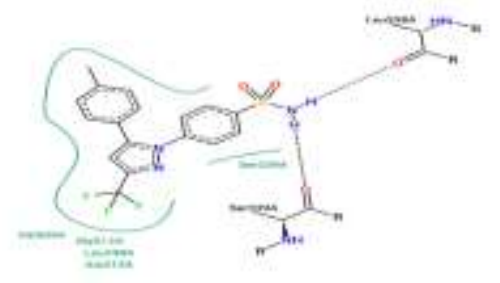

Figure 3. Visualization of Celecoxib Docking

Observation of residue contacts aims to determine interactions other than hydrogen bonds that occur between the ligand and the target protein. The residue that makes contact with the ligand has a non-binding interaction between the ligand and the target protein which will increase the affinity and inhibitory activity of the Cyclooxsigenase-2 (COX-2) enzyme. scyllitol has 1 of 2 amino acid residues similar to celecoxib, namely Ser 339A. This shows that scyllitol compounds have potential as anticancer, which in celecoxib the sulfonamide group in the hydrophilic pocket attached to the active site of COX-2 is able to specifically inhibit the COX-2 enzyme.

\section{CONCLUSION}

Based on the results of this study, it can be concluded that reticuline compounds have good stability, followed by geranyl-caproate which is seen from the value of binding energy $(\Delta \mathrm{G})$. Good secondary metabolite compounds of Annona muricata plant were shown by reticuline with a value $(\Delta \mathrm{G})$ of $-9.91 \mathrm{kcal} / \mathrm{mol}$. Furthermore, the observation of hydrogen bonding and amino acid scyllitol showed the similarity of 1 of 2 residues possessed by celecoxib, which previously had known anticancer activity. It can be concluded that curcumin and its analogues have potential as anticancer, and can be used for further drug development related to anticancer.

\section{REFERENCES}

Adri, D., Hersoelistyorini, W., 2013. Aktivitas antioksidan dan sifat organoleptik teh daun sirsak (Annona muricata Linn.) berdasarkan variasi lama pengeringan. J. Pangan Dan Gizi 4. 
Arfi, A.S., Lestari, R.D., Damayanti, D.S., 2020. Studi In Silico Senyawa Aktif Rimpang Kunyit (Curcuma domestica) Terhadap Penghambatan Acetylcholinesterase, Microtubulin (beta tubulin), dan Aktivasi Calcium Channel sebagai Terapi Antelmintik. J. Kedokt. Komunitas 8.

Cahyono, E., n.d. Artikel S1-Intermolecular Force.

Chabner, B.A., Roberts, T.G., 2005. Chemotherapy and the war on cancer. Nat. Rev. Cancer 5, 65-72.

Chen, Z., Krishnamachary, B., Penet, M.-F., Bhujwalla, Z.M., 2018. Acid-degradable dextran as an image guided siRNA carrier for COX-2 downregulation. Theranostics 8,1 .

Grösch, S., Maier, T.J., Schiffmann, S., Geisslinger, G., 2006. Cyclooxygenase-2 (COX2)-independent anticarcinogenic effects of selective COX-2 inhibitors. J. Natl. Cancer Inst. 98, 736-747.

Kern, M.A., Haugg, A.M., Koch, A.F., Schilling, T., Breuhahn, K., Walczak, H., Fleischer, B., Trautwein, C., Michalski, C., Schulze-Bergkamen, H., 2006. Cyclooxygenase-2 inhibition induces apoptosis signaling via death receptors and mitochondria in hepatocellular carcinoma. Cancer Res. 66, 7059-7066.

Mirza, D.M., 2019. Studi in silico dan in vitro aktivitas antineuroinflamasi ekstrak etanol 96\% daun Marsilea crenata C Presl. (undergraduate). Universitas Islam Negeri Maulana Malik Ibrahim.

Rio, S., Suci, E.S.T., 2017. Persepsi tentang Kanker Serviks dan Upaya Prevensinya pada Perempuan yang Memiliki Keluarga dengan Riwayat Kanker. J. Kesehat. Reproduksi 4, 159-169.

Siegel, R.L., Miller, K.D., Fedewa, S.A., Ahnen, D.J., Meester, R.G., Barzi, A., Jemal, A., 2017. Colorectal cancer statistics, 2017. CA. Cancer J. Clin. 67, 177-193.

Singh, A.K., Pandey, A., Tewari, M., Prakash, K., Shukla, H.S., Pandey, H.P., 2010. A DISCUSSION ON CHEMOPREVENTION OF ORAL CANCER BY SELECTIVE CYCLOOXYGENASE-2 (COX-2) INHIBITORS. Dig. J. Nanomater. Biostructures DJNB 5.

Sirait, A.M., Sulistiowati, E., 2014. Pengetahuan Tentang Faktor Risiko, Perilaku dan Deteksi Dini Kanker Serviks dengan Inspeksi Visual Asam Asetat (Iva) pada Wanita di Kecamatan Bogor Tengah, Kota Bogor. Indones. Bull. Health Res. 42, 20081. 